\title{
Production of bacterial cellulose by agitation culture systems
}

\author{
Takayasu Tsuchida and Fumihiro Yoshinaga
}

\author{
Bio-polymer Research Co. Ltd., 3-2-1, Sakato, Takatsu-ku-Kawasaki, JAPAN
}

\begin{abstract}
An economical mass production system of bacterial cellulose (BC) on agitated culture was constructed. We first conducted screening of BC producers in agitated culture. A total of 2096 strains were isolated from natural sources and the best BC producing strain, BPR2001, was selected. According to the taxonomic examination, we concluded that the strain belongs to a new subspecies, Acetobacter xylinum subsp. sucrofermentans subsp. nov. Of the several organic nitrogen sources used to supplement the culture medium, corn steep liquor (CSL) was found to be the most suitable for BC production. A mutant strain derived from BPR2001, BPR3001E, resistant to an analogue of PABA, sulfaguanidine, showed increased cell growth and $40 \%$ higher BC productivity than BPR2001. A host-vector system for the BC producing Acetobacter strain was then developed using an indigenous plasmid, $\mathrm{pAH} 4$, detected in BPR2001. The complete nucleotide sequence of pAH4 was determined and the shuttle vector PSA19 was constructed by connecting pAH4 to pUC18. pSA 19 was found to be very stable and the system was suitable for introducing genes into the $\mathrm{BC}$ producer in order to increase the yield of BC. Effective agitation culture systems essential for the BC ferementation with high yields were also developed. When the $\mathrm{BC}$ produced in this system was examined as a wet-end additive for papermaking processes, both the tensile strength and filler-retention of the resulting handsheets were found to be distinctly improved.
\end{abstract}

Key Words: Bacterial cellulose, Acetobacter xylinum, Agitation culture, Host-vector system, Papermaking process.

\section{INTRODUCTION}

$\mathrm{BC}$ producing by acetic acid bacteria is far superior to its counterpart from plants, because of its exceptional purity, ultra fine network structure, high biodegradability and unique mechanical strenght (ref.1). BC is expected to be used for many industrial applications as a high-strength construction material, food additive and a component of biodegradable products and paper. One of the problems that hindered the industrial application of BC is its low yield from static culture systems. Therefore, an economical mass production system based on agitated culture is necessary.

In previous works, several strains were grown by agitated cultures but all of them produced less BC than in static cultures (refs. 2,5). We thought that agitated culture was not suitable for $\mathrm{BC}$ production with regard to these strains tested but some strains suitable for $\mathrm{BC}$ production in agitated culture might exist in nature. In this study, we first established a screening system for $B C$ producers that were isolated. We isolated a strain, designated BPR2001, from a cherry as one of the most potent BC producer (ref.4). The isolate BPR2001 was examined to determine its taxonomic characteristics (ref.5). We propose a new subspecies, Acetobacter xylinum subsp. sucrofermentans as a potent BC producer.

Few reports on chemical cultural conditions of BC production by agitated culture have been published. Dudman et al. used such a culture system and studied the effects of sugar and ammonia-nitrogen concentration on BC production (ref.6). In this study, corn steep liquor (CSL) was found to be the most suitable organic nitrogen source for BPR2001. Lactate in CSL promoted both BC production and cell growth (ref.7). 
There have been some studies on breeding BC producing bacteria. Previously, BC producers with increased bacterial cellulose synthase activity have been bred by genetic engineering, with branches of their metabolic pathway blocked to decrease the amounts of by-products (refs.8,9). We bred mutant cells whose growth was increased to increase the enhancement of BC productivity (ref.10).

Several host-vector systems for $\mathrm{BC}$ producing bacteria were already available and some of these use broad host range plasmids, such as pRK311 (ref.11). pVK100 (ref.12), pRK248 (ref.13) and others have used plasmids isolated from related strains (ref.8). As a cloning vector, the use of indigenous plasmids is often very



Fig.1 A scanning Electron Micrograph of the BC Mass Produced by the Isolate BPR2001 in a Jar Fermentor useful, because they are stable. The constructed vector is also expected to be stably maintained. In this study, we describe the construction of a host-vector system in a BC producing strain, BPR2001, by using a cryptic plasmid pAH4 isolated form this strain (ref.15).

Although the BC from static culture systems has superior properties such as an ultra fine network structure, high biodegradability and unique mechanical strength as compared with green plant cellulose, it has few commercial applications due to its high price. The BC produced in an agitated culture system was examined as a wet-end additive for papermaking processes (ref.15).

\section{BODY OF RESEARCH WORK}

Screening of $B C$ producers from natural sources: A total of 547 samples from many places in Japan were collected. Buffered Schramm \& Hestrin's medium (ref.16) with $0.2 \%(\mathrm{v} / \mathrm{v})$ acetic acid, $0.5 \%(\mathrm{v} / \mathrm{v})$ ethanol, and $0.01 \%$ (w/v) cycloheximide was used for the screening. BC producing bacteria were detected in 126 of the samples (Table 1). The most efficient isolation was from fruit samples with an isolation ratio of producers to the total number of samples of over $30 \%$. No producers were detected in soil samples. A final total of 2,096 BC producers were isolated.

The amounts of $\mathrm{BC}$ accumulated by many strains were higher than those of the $\mathrm{BC}$ producing ATCC strains under both static and shaken culture conditions. A strain isolated from a black cherry showed the highest $\mathrm{BC}$ accumulations, $4.4 \mathrm{gl}^{-1}$, with CSL-Fru medium and it was selected and named BPR2001.

Taxonomic examination of strain BPR2001: A scanning electron micrograph of the unwashed product of strain BPR2001 presented in Fig.1. The isolate BPR2001 was characterized by the formation of dihydroxyacetone from
TABLE 1 The Results of Screening for BC Producers from Natural Sources

\begin{tabular}{|l|c|c|c|}
\hline \multirow{2}{*}{ Sources } & \multicolumn{2}{|c|}{ Number of samples } & Ratio of isolation of \\
\cline { 2 - 4 } & tested & $\begin{array}{c}\text { containing } \\
\text { cellulose producer }\end{array}$ & cellulose producer (\%) \\
\hline Fruits & 353 & 112 & 31.7 \\
Nuts & 28 & 3 & 10.7 \\
Sugar Cane & 124 & 9 & 7.3 \\
Flowers & 35 & 2 & 5.6 \\
Soil & 6 & 0 & 0 \\
\hline Total & 547 & 126 & 23.0 \\
\hline
\end{tabular}


TABLE 2 DNA Homologies between the Isolate BPR2001 and the Type Strains of Acetobacter species

\begin{tabular}{|c|c|c|c|c|}
\hline \multirow{2}{*}{$\begin{array}{c}\text { Source of labeled } \\
\text { DNA }\end{array}$} & \multicolumn{4}{|c|}{ \% Relative binding of DNA } \\
\hline & $\begin{array}{c}\text { Isolate } \\
\text { BPR2001 }\end{array}$ & $\begin{array}{l}\text { A.xylinum } \\
\text { IFO } 15237^{T}\end{array}$ & $\begin{array}{c}\text { A.hansenii } \\
\text { ATCC } 35959^{T}\end{array}$ & $\begin{array}{l}\text { A.pasteurianus } \\
\text { ATCC } 33445^{\mathrm{T}}\end{array}$ \\
\hline Isolate BPR2001 & 100 & 58.2 & 15.6 & 0.3 \\
\hline $\begin{array}{l}\text { A.xylinum IFO } \\
1523^{\mathrm{T}}\end{array}$ & 56.5 & 100 & 24.3 & 9.1 \\
\hline
\end{tabular}

glycerol and by ubiquinone- 10 . The DNA homologies of the isolate BPR2001 were estimated to be low $(15.6 \%$ and $0.3 \%$ ), when hybridized with the DNAs of the type strains of Acetobacter hansenii and Acetobacter pasteurianus respectively. However, the DNA of the isolate BPR2001 hybridized to the extent of $58.2 \%$ with that of the type strain of Acetobacter xylinum (Table 2).

The isolate BPR2001 was distinguishable phenotypically from the type strain of Acetobacter xylinum by growing on ethanol, glycerol, dulcitol, and sucrose, by acid formation from D-galactose, glycerol, mesoerythritol, sucrose and trehalose, and by oxidation of glycerol, D-mannitol and lactose (Table 3). We proposed a new subspecies, Acetobacter xylinum subsp. sucrafermentans as a potent BC producer.

Stimulation of $B C$ productivity by addition of $C S L$ : We examined the effects of various organic nitrogen

TABLE 3 Comparison of Physiological and Biochemical Characteristics of the Isolate BPR2001 and Type Strains of Acetobacter species

\begin{tabular}{|c|c|c|c|}
\hline & $\begin{array}{c}\text { Isolate } \\
\text { BPR } 2001\end{array}$ & $\begin{array}{l}\text { A. xylinum } \\
\text { IFO } 15237^{\mathrm{T}}\end{array}$ & $\begin{array}{c}\text { A. hansenii } \\
\text { ATCC } 35959^{\mathrm{T}}\end{array}$ \\
\hline \multicolumn{4}{|l|}{ Oxidation of } \\
\hline D- Fructose & - & - & + \\
\hline D-Glucose & + & + & + \\
\hline Glycerol & + & - & + \\
\hline meso-Erythritol & + & \pm & + \\
\hline D-Mannitol & + & - & + \\
\hline Lactose & + & - & + \\
\hline Sucrose & - & - & - \\
\hline \multicolumn{4}{|l|}{ Growth on } \\
\hline Ethanol & + & - & + \\
\hline D-Xylose & \pm & + & + \\
\hline D-Galactose & \pm & + & \pm \\
\hline D-Glucose & + & + & + \\
\hline Glycerol & + & - & + \\
\hline meso-Erythritol & + & + & + \\
\hline Dulcitol & \pm & - & + \\
\hline Lactose & $\cdot$ & - & - \\
\hline Maltose & - & - & - \\
\hline Sucrose & + & - & - \\
\hline Trehalose & \pm & \pm & + \\
\hline \multicolumn{4}{|l|}{ Acid Formation from } \\
\hline D-Xylose & + & + & + \\
\hline D-Galactose & + & - & + \\
\hline D-Glucose & + & + & + \\
\hline Glycerol & \pm & - & + \\
\hline meso-Erythritol & + & - & + \\
\hline Dulcitol & - & - & + \\
\hline Lactose & - & - & - \\
\hline Maltose & - & - & - \\
\hline Sucrose & + & - & - \\
\hline Trehalose & + & - & + \\
\hline
\end{tabular}
hand, factors which promote the growth of and BC production by strain BPR2001 were investigated. It was sources on $\mathrm{BC}$ production. When $0.24 \%$ $\mathrm{w} / \mathrm{v}$ (of the total nitrogen) soytone, yeast extract (YE), CSL or peptone was added to the basal medium, cell growth and $\mathrm{BC}$ production were stimulated only by CSL. The amounts of $\mathrm{BC}$ produced with the other nitrogen sources were almost the same as that in basal medium without organic nitrogen. Therefore, CSL was found to be the most suitable organic nitrogen source for $\mathrm{BC}$ production by the strain BPR2001.

To investigate the effects of CSL in detail, the chemical composition of all the organic nitrogen sources used, soytone, YE, and peptone, was analyzed. The major difference was that CSL contained lactate. The addition of lactate stimulated cell growth and $\mathrm{BC}$ production. The amounts of $\mathrm{BC}$ produced in lactate-supplemented media containing soytone or $\mathrm{YE}$ were almost the same as that in basal medium containing only CSL. These results suggested that lactate in CSL stimulated cell growth and $\mathrm{BC}$ production.

Increase in $B C$ production by sulfaguanidine-resistant mutants: The relationship between $\mathrm{BC}$ production and cell growth was investigated and the production was found to be growth associated. Thus, it was expected that enhanced cell growth would lead to enhanced BC production. On the other 
found that the addition of p-aminobenzoic acid (PABA) promoted these effects. Therefore, mutants resistant to sulfaguanidine (SG), which is an analogue of PABA, were bred from BPR2001. Forty-one SG resistant mutants were obtained from about 60,000 BPR2001 cells through NTG-treatment. The distribution of BC production among these SG-resistant mutants was tested. The best BC producer, BPR3001E, was selected.

Cell growth and $\mathrm{BC}$ production by the SG-resistant mutant BPR3001E were examined. The course of BC production by BPR3001E compared with BPR2001 in a jar fermentor was tested (Fig.2). Cell growth and BC production of BPR3001E were found to be higher than those of BPR2001. BPR3001E produced $9.7 \mathrm{gl}^{-1}$ of BC from $44 \mathrm{gl}^{-1}$ fructose. The $\mathrm{BC}$ production by the mutant was $40 \%$ greater than by BPR2001.

Construction of a host-vector system: An indigenous plasmid, named pAH4, was detected in a BC-producing strain BPR2001. This plasmid, consisting of 4002 base pairs contained an AT-rich region and encoded several open reading frames, as deduced by the complete nucleotide sequence. One of the putative open reading frames showed homology with replication proteins of other plasmids. A shuttle vector was constructed from Escherichia coli and this strain BPR2001 was constructed by connecting pAH4 to pVC18 (Fig.3). Electroporation of the shuttle vector into the strain BPR2001 yielded $1.7 \times 10^{-5}$ ampicillin resistant transformants per $\mu \mathrm{gDNA}$ (Table 4). The shuttle vector was very stably maintained in the strain BPR 2001 .

TABLE 4 Transformation Efficiency of BPR2001 with the Shuttle Vector

\begin{tabular}{|l|c|c|}
\hline \multicolumn{1}{|c|}{$\begin{array}{c}\text { Plasmid } \\
\text { (pSA 19) }\end{array}$} & $\begin{array}{c}\text { From } \\
\text { E. coli }\end{array}$ & $\begin{array}{c}\text { From } \\
\text { BPR2001 }\end{array}$ \\
\hline $\begin{array}{l}\text { Transformation } \\
\text { Efficiency } \\
\text { (cfu/ } / \text { g DNA) }\end{array}$ & 10 & $1.7 \times 10^{5}$ \\
\hline
\end{tabular}

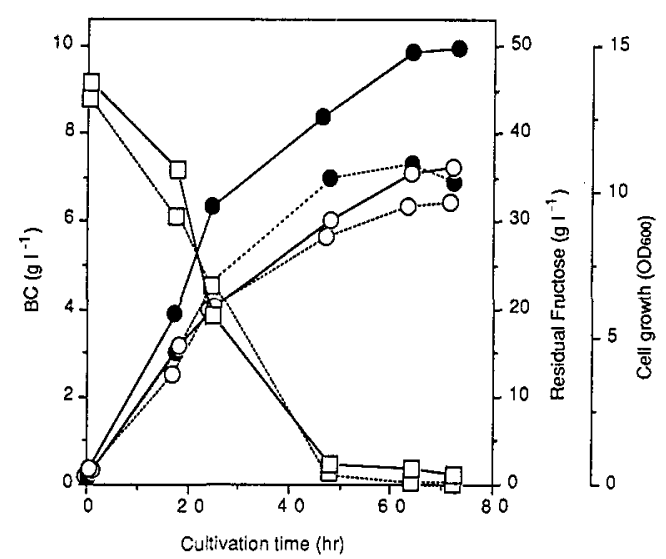

Fig.2 Course of BC Production by BPR2001 and BPR3001E Dotted line, BPR2001; solid line, BPR3001E. Open circles, cell growth; closed circles, BC production; open squares, residual fructose

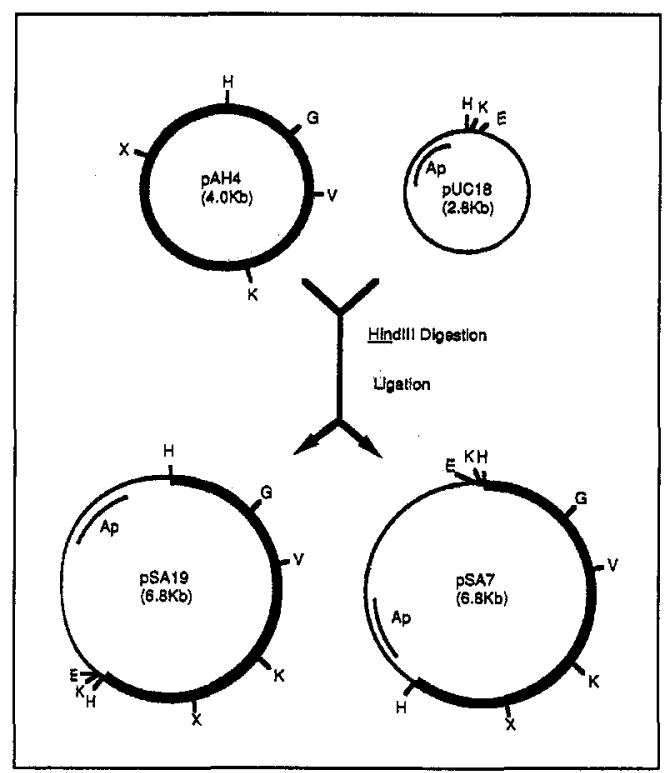

Fig.3 Construction of Shuttle Vectors

$B C$ as a new material for papermaking: The application of $\mathrm{BC}$ to papermaking was investigated.The morphology of $\mathrm{BC}$ observed through a scanning electron micrograph comprises ultrafine fibrils which are approximately $1 / 100$ width of pulp fibre. The BC can be obtained with two typical cultural methods, namely static and agitated culture. We have found some structural differences between these two types of BC. We, therefore, investigated the properties of the BCs for papermaking.

When these two types of BCs were added at the wet-end of paper production, both tensile strength and fillerretention of the handsheets were improved (Figs. 4 \& 5). In particular, the BC from agitated cultures had enhanced effects on filler-retention than that from static cultures. 


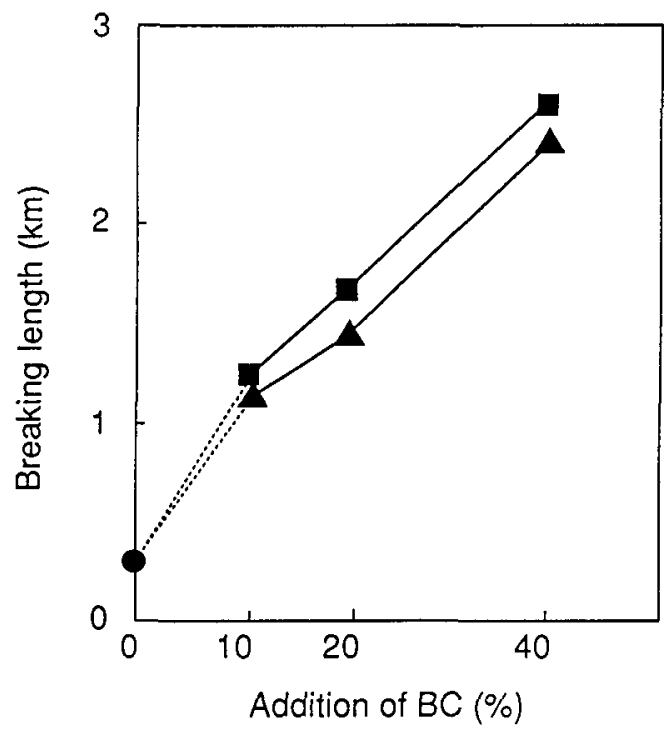

Fig. 4 Dry Strength of Paper Containing BC

-D BC from static culture

A-A BC from agitated culture



Fig.5 Effect of BC of Filler-Retension

11- $\mathrm{BC}$ from static culture

A-A BC from agitated culture

\section{CONCLUSIONS}

The bacterial cellulose producer that yielded the highest polymer accumulation in agitated culture and obtained from natural sources was named BPR2001. According to the taxonomic examination, this strain BPR2001 is designated as a new subspecies, Acetobacter xylinum subsp. sucrofermentas subsp.nov. CSL was found to be the most suitable organic nitrogen source for BC production. Lactate in CSL stimulated cell growth and $\mathrm{BC}$ production. As sulfaguanidine resistant mutant BPR3001E derived from BPR2001 showed increased cell growth and $40 \%$ higher BC productivity. A host-vector system for a BC-producing strain was developed by using an indigenous plasmid, pAH4 found in BPR2001. The BC produced in the agitated culture when incorporated at the wet-end of the papermaking process enhanced both the tensile strength and filler-retention of the product.

\section{REFERENCES}

1. S.Yamanaka, K.Watanabe, N.Kitamura, M.Iguchi, S.Mitsuhasi, Y.Nishi and M.Urya. J. Mater.Sci., 24, 3141-3145 (1989)

2. S. Yamanaka in Cellulosics Utilization-Research and Rewards in Cellulosics, ed. H. Inagaki and G.O.Phillips, Elsevier Science Publishers Ltd., England, 1989. pp175-181.

3. M.Schramm and S.Hestrin, J.Gen Microbiol. 11 123-129 (1954)

4. H.Toyosaki, T.Naritomi, A.Seto, M.Matsuoka, T.Tsuchida and F.Yoshinaga, Biosci.Biotech.Biochem., 59 1489-1502 (1995)

5. H. Toyosaki, Y.Kojima, T.Tsuchida, K.Hoshino, Y.Yamada and F.Yoshinaga. J. Gen. Appl. Microbiol., 41b 307-314 (1995)

6. W.F. Dudmann, J. Gen. microbiol., 22 25-30 (1960)

7. M. Matsuoka, T.Tsuchida, K.Mastushita, O.Adachi and F.Yoshinaga, Biosci. Biotech. Biochem., 60 575-579 (1996)

8. H.C. Wong, A.L.Fear, R.D.Calhoon, G.H.Eichinger, R.Mayer, D.Amikam, M.Benziman, D.H.Gelfand, J.H.Meade, A.W.Emerick, R.Bruner, A.Ben-Bassat and R.Tal, Proc.Natl.Sci., USA, 78 8130-8134 (1990) 
9. A.Ben-Bassat, R.Buner, S.Shoemkaer, Y.Aloni, H.C.Wong, D.C.Johnson, A.N.Neogi US Patent $5,079,162(1992)$

10. A.Ashikawa, M.Matsuoka, T.Tsuchida and F. Y'oshinaga, Biosci.Biotech.Biochem. 59 2259-2262 (1995)

11. E.Fjaervik, K.Frydenlund, S.Valla, Y.Huggirat and M.Benziman FEMS Microbiol.Lett., 77 325$330(1991)$

12. S.Valla, D.H.Coucheron, E.Fjaervik, J.Kjosbakken, H.Weinhouse, P.Ross, D.Amikam and M.Benziman Mol.Gen.Genet. 217 26-30 (1989)

13. P.E.Hall, S.M.Anderson, D.M.Johnston and R.E.Cannon Plasmid 28 194-200

14. N.Tonouchi, T.Tsuchida, F.Yoshinaga, S.Horinouchi and T.Beppu, Biosci.Biotech.Biochem 58 1899-1901 (1994)

15. N.Hioki, Y.Hori, K.Watanabe, Y.Morinaga, F.Yoshinaga, Y.Hibino and T.Ogura, Japan Tappi Journal 49 718-723 (1995)

16. S.Hestrin and M.Schramm Biochem.J., 58 345-352 (1954). 